\title{
Pengaruh Komunikasi Keluarga dan Disiplin Belajar Terhadap Prestasi Belajar Siswa Kelas V Sekolah Dasar
}

\author{
N Istiqlalia \\ SD Negeri Sukorejo \\ istiqlalianafsiyatul@gmail.com
}

\section{Article History}

received 3/12/2020

revised 17/12/2020

accepted 31/12/2020

\begin{abstract}
The aim of this research is 1) To know the influence of family commucation to students' achievmen; 2) to know learning dicipline to students' achievment; 3) to know the influence of family communication and dicipline to students' achievement in the fifth grade. The kind of this research is quantitative research. the population is the fifth grade students in SD Negeri Sukorejo elementary school. The technique of collectig data is questionare and documentation. the instrument test is validity and realibility test. The result of this research is 1) family communication has possitif effect and significant to students achievment in SD Negeri Sukorejo elemntary school, suruh, semarang regency 2020/2021 academic year 2)learning dicipline haspossitif effect and significant to students achievment in SD Negeri Sukorejo elemntary school, suruh, semarang regency 2020/2021 academic year3) both of family communication and learning dicipline have influence to students achievement in gunungtumpeng elemntary school, suruh, semarang regency 2020/2021 academic year 4) communication variable gives $216 \%$ of the effectiveness, learning vriable gives $18,9 \%$ of the effectiveness. the amount of them is $40,5 \%$, while $59,5 \%$ is residue that it influenced by the other variable.
\end{abstract}

Keywords: family communiction, learning dicipline, students achievement

\begin{abstract}
Abstrak
Tujuan penelitian ini adalah 1) Untuk mengetahui pengaruh komunikasi keluarga terhadap prestasi belajar; 2) untuk mengetahui disiplin belajar terhadap prestasi belajar siswa; 3) Untuk mengetahui Pengaruh Komunikasi dan Disiplin Keluarga terhadap Prestasi Belajar Siswa Kelas V SD. Jenis penelitian ini adalah penelitian kuantitatif. populasinya adalah siswa kelas V SD Negeri Sukorejo. Teknik pengumpulan datanya adalah angket dan dokumentasi. Uji instrumennya adalah uji validitas dan uji reliabilitas. Hasil penelitian ini adalah 1) komunikasi keluarga berpengaruh positif dan signifikan terhadap prestasi belajar siswa SD Negeri Sukorejo suruh kabupaten semarang tahun ajaran 2020/2021 2) disiplin belajar berpengaruh positif dan signifikan terhadap prestasi belajar siswa SD Negeri Sukorejo sekolah, suruh, kabupaten semarang tahun pelajaran 2020/20213) baik komunikasi keluarga dan disiplin belajar berpengaruh terhadap prestasi belajar siswa di sekolah dasar gunungtumpeng, suruh, kabupaten semarang tahun pelajaran 2020/2021 4) variabel komunikasi memberikan efektivitas $216 \%$, pembelajaran variabel memberikan efektivitas sebesar $18,9 \%$. jumlahnya adalah $40,5 \%$, sedangkan $59,5 \%$ adalah residu yang dipengaruhi oleh variabel lain.
\end{abstract}

Kata kunci: komunikasi keluarga, disiplin belajar, prestasi siswa

Social, Humanities, and Education Studies (SHEs): Conference Series https://jurnal.uns.ac.id/shes

p-ISSN 2620-9284

e-ISSN 2620-9292 


\section{PENDAHULUAN}

Anak sebagai siswa menjadi sasaran utama dalam kegiatan pendidikan, di mana mereka diharapkan dapat mencapai keberhasilan belajar. Keberhasilan belajar siswa dapat dilihat dari kemampuannya dalam menguasai materi pelajaran, hasil belajar yang dicapai siswa, keterampilan dan kebenaran dalam menyelesaikan tugas yang diberikan guru. Berdasarkan observasi yang dilakukan di SD Negeri Sukorejo, prestasi belajar siswa belum dapat dikatakan baik, siswa masih belum bersungguh-sungguh untuk belajar. Indikasi tersebut dapat dilihat dari prestasi belajar beberapa mata pelajaran pada ulang harian yang masih rendah. Rendahnya prestasi belajar yang dicapai oleh siswa, diduga oleh rendahnya disiplin belajar. Dalam hal belajar siswa akan berhasil jika dalam dirinya sendiri ada kemauan untuk belajar dan disiplin untuk belajar. Disiplin belajar merupakan salah satu unsur yang penting dalam proses pembelajaran baik sebelum, selama, ataupun setelah proses pembelajaran dikelas.

Hal ini sesuai dengan pendapat Imron (2004: 135) menyatakan bahwa "orangorang yang berhasil dalam bidangnya masing-masing umumnya mempunya disiplin yang tinggi. Sebaliknya orang yang gagal, umumnya tidak disiplin". Maksudnya apabila seorang siswa mempunyai disiplin yang tinggi maka nantinya siswa tersebut akan memperoleh hasil belajar yang baik dan begitu juga sebaliknya apabila seorang siswa memiliki disiplin yang rendah maka siswa tersebut akan memperoleh hasil belajar yang kurang baik. Berdasarkan observasi awal yang telah dilakukan dan wawacara dengan guru di SD Negeri Sukorejo Suruh Kabupaten Semarang menyatakan bahwa tingkat disiplin belajar siswa masih kurang. Hal ini dapat dilihat dari masih banyak siswa yang mengabaikan tanggung jawabnya sebagai pelajar yang ditunjukkan oleh sikap dan tindakannya yang tidak mentaati peraturan sekolah seperti terlambat masuk ke kelas, tidak memakai seragam yang rapi dan lengkap ke sekolah, tidak mengerjakan tugas, mengerjakan PR di kelas, tidak memperhatikan guru pada saat pelajaran, berkelahi dengan temannya, dan sering membolos. Perilaku semacam ini menunjukkan bahwa tingkat disiplin belajar siswa masih kurang. Disamping itu juga dalam rangka meningkatkan mutu pendidikan dan mencapai sumber daya yang berkualitas sesuai dengan standar kompetensi yang ditetapkan secara nasional, komunikasi interpesonal keluarga juga mempengaruhi proses belajar siswa yang pada akhirnya berpengaruh pada hasil belajar siswa.

Faktor eksternal yang mempengaruhi prestasi belajar adalah lingkungan keluarga. Menurut Purwanto (1996: 107), lingkungan yaitu lingkungan alam seperti lingkungan tempat siswa berada rumah tempat tinggal, gedung sekolah dan letaknya dan lingkungan sosial seperti para guru, teman- teman se kelas serta orang tua". Faktor eksternal keluarga memiliki pengaruh terhadap proses belajar dan hasil belajar hasil siswa. Komunikasi adalah suatu sarana untuk dapat menciptakan hubungan yang harmonis antara keluarga dengan anak. Komunikasi antara orang tua dengan anak sangat berperan dalam menentukan keberhasilan proses belajar anak dan membantu perkembangan kepribadian anak. Adanya komunikasi yang baik antara keluarga dengan anak akan dapat meningkatkan motivasi belajar anak. Komunikasi yang dilakukan oleh orang tua dengan anak harus dilandasi hubungan yang mesra, penuh kasih sayang dan pengertian. Komunikasi interpersonal keluarga akan menciptakan saling pengertian, kepercayaan, menghargai, dan mempererat hubungan social. Hal ini mampu mengatasi konflik, menjadi sesuatu yang membangun dan secara professional menerapkan teknik berkomunikasi. Bila semua dapat dilakukan akan tercipta situasi belajar yang kondusif, motivasi belajar yang tinggi, dan itu berarti hasil belajar meningkat secara proporsional karena dilaksanakan dengan penuh tanggungjawab dan kerja keras.

Berhasil tidaknya pendidikan siswa di sekolah tidak lepas dari pengaruh orang tua, serta persoalan yang dihadapi oleh siswa dalam lingkungan keluarga. Walgito (1997: 136) menyatakan bahwa seringnya anak dan orang tua berkomunikasi akan 
mempengaruhi siswa untuk berprestasi dan tingkah laku yang baik,anak yang jarang bertemu dan berkomunikasi dengan orang tua disebabakan oleh orang tua sibuk, menunjukan perilaku yang kurang baik terhadap hasil belajar anak. Kenyataan yang sering ditemui tidak sedikit orang tua yang masih beranggapan kalau anak-anaknya sudah diserahkan kepada guru disekolah, maka selesai sudah tugas mereka dalam mendidik anak. Para orang tua beranggapan bahwa tugas mereka sekarang adalah mencari uang untuk membiayai sekolah anak-anak mereka. Selain itu ada juga karena kesibukan kerja orang tua kurang memiliki waktu untuk memperhatikan anaknya belajar di rumah. Ketika sampai di rumah orang tua juga jarang berkomunikasi dengan anak. Orang tua hampir tidak pernah bertanya tentang kegiatan sehari-hari yang dilakukan oleh anak-anak mereka baik di sekolah maupun di rumah.

Berdasarkan wawancara yang peneliti lakukan dengan beberapa orang siswa SD Negeri Sukorejo Semarang tahun pelajaran 2020/2021, diketahui bahwa diantara mereka ada yang jarang berkomunikasi dengan keluarganya terutama dengan orang tua tentang pelajaran mereka di sekolah. Orang tua jarang bertanya seputar kegiatan anak di sekolah, misalnya apa saja yang dilakukan di sekolah, kesulitan pelajaran di sekolah dan ada tidaknya pekerjaan rumah yang diberikan oleh guru. Kurangnya perhatian dan ketiadaan komunikasi orang tua kepada anak cenderung membuat anak menjadi tidak mempunyai semangat belajar. Rendahnya semangat belajar anak tentu saja akan mempengaruhi hasil belajarnya di sekolah. Berdasarkan uraian di atas, maka ditentukan penelitian dengan judul "Pengaruh Komunikasi Keluarga dan Disiplin Belajar terhadap Prestasi Belajar Siswa Kelas V SD Negeri Sukorejo Suruh Kabupaten Semarang Tahun Pelajaran 2020/2021"

\section{METODE}

Penelitian ini merupakan jenis penelitian kuantitatif. Menurut Azwar (2010: 5-9), penelitian kuantitatif adalah penelitian yang lebih menekankan analisisnya pada datadata numerikal (angka) yang diolah dengan metode statistika. Desain penelitian yang digunakan adalah desain penelitian korelasional.

Desain penelitian korelasional ditujukan untuk menetapkan besarnya arah hubungan antara variabel-variabel. Hubungan tersebut adalah hubungan antara variabel komunikasi keluarga dan disiplin belajar dengan prestasi belajar siswa. Penelitian ini dilakukan di SD Negeri Sukorejo Suruh Kabupaten Semarang. Penelitian ini dilakukan pada bulan Februari 2020 sampai Mei 2020. Populasi dalam penelitian ini adalah siswa kelas V SD Negeri Sukorejo Suruh Kabupaten Semarang Tahun Pelajaran 2020/2021. Alasan dipilihnya kelas V karena sudah dapat melakukan pengisian angket secara mandiri.

Penelitian ini menggunakan sampel bertujuan (proporsive sampling). Hal ini dikarenakan penelitian ini memiliki tujuan yaitu ingin mengetahui pengaruh komunikasi keluarga dan disiplin belajar terhadap prestasi belajar siswa SD Negeri Sukorejo Suruh Kabupaten Semarang Tahun Pelajaran 2020/2021.

Variabel independen (variabel bebas) yaitu komunikasi keluarga dan disiplin belajar. Variabel dependen (variabel terikat) yaitu prestasi belajar. Teknik pengumpulan data yang digunakan dalam penelitian ini adalah metode angket/quesioner dan dokumentasi. Teknik pengujian instrumen dalam penelitian ini mengunakan uji validitas dan uji reliabilitas. Teknik analisis data dalam penelitian ini menggunakan teknik uji prasyarat analisis, analisis regresi berganda, uji $f$, uji t, koefisien determinasi, dan sumbangan relatif dan sumbangan efektif.

\section{Analisis data}

\section{HASIL DAN PEMBAHASAN}

\section{Analisis Regresi Linier Ganda}


Dalam penelitian ini persamaan umum dari regresi ganda yang digunakan adalah $\mathrm{Y}=\mathrm{a}+\mathrm{b}_{1} \mathrm{X}_{1}+\mathrm{b}_{2} \mathrm{X}_{2}$. Berdasarkan hasil analisis regresi ganda dengan program SPSS for Windows versi 15 diperoleh data sebagai berikut:

Tabel 1. Rangkuman Hasil Uji Regresi Linier Ganda

\begin{tabular}{lccc}
\hline \multicolumn{1}{c}{ Variabel } & $\begin{array}{c}\text { Koefisien } \\
\text { Regresi }\end{array}$ & $\mathbf{t}_{\text {hitung }}$ & Sig. \\
\hline Konstanta & 6,581 & & \\
Komunikasi Keluarga & 0,031 & 2,412 & 0,026 \\
Disiplin Belajar & 0,036 & 2,225 & 0,038 \\
F $_{\text {hitung }}$ & 6,470 & & \\
$\mathrm{R}^{2}$ & 0,405 & & \\
\hline
\end{tabular}

\section{Uji t}

a. Pengaruh komunikasi keluarga tehadap prestasi belajar.

Dari analisis regresi ganda diketahui bahwa koefisien regresi dari variabel komunikasi keluarga $\left(b_{1}\right)$ bernilai positif sebesar 0,031 , sehingga dapat dikatakan bahwa komunikasi keluarga berpengaruh positif terhadap prestasi belajar. Untuk mengetahui pengaruh tersebut signifikan atau tidak, selanjutnya nilai koefisien regresi linier ganda dari $b_{1}$ ini diuji signifikansinya. Langkah-langkah uji signifikansi koefisien regresi atau disebut juga uji t adalah sebagai berikut:

1) Hipotesis

Ho: $\beta_{1}=0$ Berarti tidak ada pengaruh yang signifikan komunikasi keluarga terhadap prestasi belajar.

$\mathrm{H}_{1}: \beta_{1} \neq 0$ Berarti ada pengaruh komunikasi keluarga terhadap prestasi belajar.

2) Tingkat Signifikansi $95 \%, \alpha=0,05$

3) Kriteria pengujian

Ho diterima apabila $-\mathrm{t}_{(\alpha / 2 ; n-k-1) \leq} \mathrm{t}_{\leq} \mathrm{t}_{(\alpha / 2 ; n-k-1)}$ atau signifikansi $>0,05$

Ho ditolak apabila $-\mathrm{t}>\mathrm{t}_{(\alpha / 2 ; n-k-1)}$ atau $\mathrm{t}<-\mathrm{t}_{(\alpha / 2 ; n-k-1)}$ atau signifikansi $<0,05$

$t_{\text {tabel }}=\mathrm{t}_{(\mathrm{a} / 2, \mathrm{n}-\mathrm{k}-1)}=\mathrm{t}_{(0,025 ; 19)}=2,093$

4) Perhitungan

Berdasarkan hasil analiais data yang telah dilakukan dengan program SPSS for Windows versi 15 diperoleh nilai thitung sebesar 3,044 dengan signifikansi 0, 016.

5) Keputusan uji

$\mathrm{H}_{0}$ ditolak, karena thitung $>t_{\text {tabel }}$ yaitu 3,044>2,093 dengan nilai probabilitas signifikansi< 0,05 , yaitu 0,016 .

6) Kesimpulan

Ada pengaruh yang signifikan komunikasi keluarga terhadap prestasi belajar siswa SD Negeri Sukorejo Suruh Kabupaten Semarang Tahun Pelajaran 2020/2021.

b. Pengaruh disiplin belajar terhadap prestasi belajar.

Langkah-langkah uji signifikansi koefisien regresi atau disebut juga uji t adalah sebagai berikut: 
1) Hipotesis

Ho: $\beta_{2}=0$ Berarti tidak ada pengaruh yang disiplin belajar terhadap prestasi belajar.

$\mathrm{H}_{1}: \beta_{2} \neq 0$ Berarti ada pengaruh yang signifikan disiplin belajar terhadap prestasi belajar.

2) Tingkat Signifikansi $95 \%, \alpha=0,05$

3) Kriteria pengujian

Ho diterima apabila $-\mathrm{t}_{(\alpha / 2 ; n-\mathrm{k}-1) \leq} \leq \mathrm{t} \leq \mathrm{t}_{(\alpha / 2 ; \mathrm{n}-\mathrm{k}-1)}$ atau signifikansi

$>0,05$

Ho ditolak apabila $-\mathrm{t}>\mathrm{t}_{(\alpha / 2 ; n-k-1)}$ atau $\mathrm{t}<-\mathrm{t}_{(\alpha / 2 ; n-k-1)}$ atau signifikansi $<0,05$

$\mathrm{t}_{\text {tabel }}=\mathrm{t}_{(\mathrm{a} / 2, \mathrm{n}-\mathrm{k}-1)}=\mathrm{t}_{(0,025 ; 19)}=2,093$

4) Perhitungan

Berdasarkan hasil analisis data yang telah dilakukan dengan program SPSS for Windows versi 15 diperoleh nilai thitung sebesar 2,095 dengan signifikansi 0, 000.

5) Keputusan uji

$\mathrm{H}_{0}$ ditolak, karena $t_{\text {hitung }}>\mathrm{t}_{\text {tabel }}$ yaitu $2,412>2,093$ dengan nilai probabilitas signifikansi $<0,05$, yaitu 0,000 .

6) Kesimpulan

Ada pengaruh yang signifikan disiplin belajar terhadap prestasi belajar siswa SD Negeri Sukorejo Suruh Kabupaten Semarang Tahun Pelajaran 2020/2021.

\section{Uji F}

a) Hipotesis

Ho: $\beta_{1}=\beta_{2}=0$ Berarti tidak ada pengaruh komunikasi keluarga dan disiplin belajar secara bersama-sama terhadap prestasi belajar.

$H_{1}: \beta_{1} \neq \beta_{2} \neq 0$ Berarti ada pengaruh komunikasi keluarga dan disiplin belajar secara bersama-sama terhadap prestasi belajar.

b) Taraf signifikansi $95 \%, \alpha=0,05$

c) Kriteria pengujian

$\mathrm{H}_{0}$ diterima apabila $\mathrm{F}_{\text {hitung }}<\mathrm{F}_{(\mathrm{a}, \mathrm{k} ; \mathrm{n}-\mathrm{k}-1)}$ atau signifikansi $>0,05$

$\mathrm{H}_{0}$ ditolak apabila $\mathrm{F}_{\text {hitung }}>\mathrm{F}_{(\mathrm{a}, \mathrm{k} ; \mathrm{n}-\mathrm{k}-\mathrm{1})}$ atau signifikansi $<0,05$

$\mathrm{F}_{\text {tabel }}=\mathrm{F}_{(\mathrm{a}, \mathrm{k} ; \mathrm{n}-\mathrm{k}-1)}=\mathrm{F}_{(0,05 ; 2,19)}=3,520$

d) Perhitungan

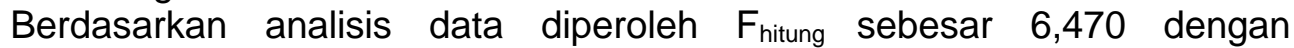
signifikansi sebesar 0, 019 .

e) Keputusan uji

$\mathrm{H}_{0}$ ditolak, karena $\mathrm{F}_{\text {hitung }}>\mathrm{F}_{\text {tabel, }}$ yaitu $6,470>3,520$ dan nilai probabilitas signifikansi < 0, 05, yaitu 0, 019 .

f) Kesimpulan

Ada pengaruh pengaruh komunikasi keluarga dan disiplin belajar secara bersama-sama terhadap prestasi belajar siswa SD Negeri Sukorejo Suruh Kabupaten Semarang Tahun Pelajaran 2019/2020.

4. Koefisien Determinasi

Berdasarkan analisis data menggunakan alat bantu program SPSS 15.0 diperoleh nilai kofisien determinasi $\left(R^{2}\right)$ sebesar 0,405 . Arti dari koefisien ini adalah bahwa pengaruh yang diberikan oleh kombinasi variabel komunikasi keluarga dan disiplin belajar secara bersama-sama terhadap prestasi belajar siswa SD Negeri Sukorejo Suruh Kabupaten Semarang Tahun Pelajaran 
$2021 / 2020$ adalah sebesar $34 \%$, sedangkan sisanya dipengaruhi oleh variabel lain.

5. Sumbangan Relatif (SR\%) dan Sumbangan Efektif (SE\%)

Berdasarkan hasil perhitungan diketahui bahwa variabel komunikasi keluarga memberikan sumbangan relatif sebesar $53,3 \%$ dan sumbangan efektif $21,6 \%$. Variabel disiplin belajar memberikan sumbangan relatif sebesar $46,7 \%$ dan sumbangan efektif $18,9 \%$. Berdasarkan besarnya sumbangan relatif dan efektif nampak bahwa variabel komunikasi keluarga mempunyai pengaruh yang paling besar terhadap prestasi belajar siswa SD Negeri Sukorejo Suruh Kabupaten Semarang Tahun Pelajaran 2020/2021 dibandingkan dengan variabel disiplin belajar.

g) Kesimpulan

Ada pengaruh pengaruh komunikasi keluarga dan disiplin belajar secara bersama-sama terhadap prestasi belajar siswa SD Negeri Sukorejo Suruh Kabupaten Semarang Tahun Pelajaran 2020/2021.

6. Koefisien Determinasi

Berdasarkan analisis data menggunakan alat bantu program SPSS 15.0 diperoleh nilai kofisien determinasi $\left(R^{2}\right)$ sebesar 0,405 . Arti dari koefisien ini adalah bahwa pengaruh yang diberikan oleh kombinasi variabel komunikasi keluarga dan disiplin belajar secara bersama-sama terhadap prestasi belajar siswa SD Negeri Sukorejo Suruh Kabupaten Semarang Tahun Pelajaran 2019/2020 adalah sebesar 34\%, sedangkan sisanya dipengaruhi oleh variabel lain.

7. Sumbangan Relatif (SR\%) dan Sumbangan Efektif (SE\%)

Berdasarkan hasil perhitungan diketahui bahwa variabel komunikasi keluarga memberikan sumbangan relatif sebesar $53,3 \%$ dan sumbangan efektif $21,6 \%$. Variabel disiplin belajar memberikan sumbangan relatif sebesar $46,7 \%$ dan sumbangan efektif $18,9 \%$. Berdasarkan besarnya sumbangan relatif dan efektif nampak bahwa variabel komunikasi keluarga mempunyai pengaruh yang paling besar terhadap prestasi belajar siswa SD Negeri Sukorejo Suruh Kabupaten Semarang Tahun Pelajaran 2020/2021 dibandingkan dengan variabeldisiplin belajar.

\section{SIMPULAN}

Berdasarkan analisis dan pembahasan yang telah diuraikan pada bab sebelumnya, maka dapat diambil kesimpulan sebagai berikut :

Komunikasi keluarga berpengaruh positif dan signifikan terhadap prestasi belajar siswa SD Negeri Sukorejo Suruh Kabupaten Semarang Tahun Pelajaran 2020/2021.

Disiplin belajar berpengaruh positif dan signifikan terhadap prestasi belajar siswa SD Negeri Sukorejo Suruh Kabupaten Semarang Tahun Pelajaran 2020/2021.

omunikasi keluarga dan disiplin belajar secara bersama-sama terhadap prestasi belajar siswa SD Negeri Sukorejo Suruh Kabupaten Semarang Tahun Pelajaran 2020/2021.

??. Variabel komunikasi keluarga memberikan sumbangan efektif $21,6 \%$. Variabel disiplin belajar memberikan sumbangan efektif $18,9 \%$. sehingga total sumbangan efektif kedua variabel sebesar $40,5 \%$, sedangkan $59,5 \%$ sisanya dipengaruhi oleh variabel lain yang tidak diteliti.

\section{DAFTAR PUSTAKA}

Achmad, A.S. 1992. Komunikasi, Media Massa dan Khalayak. Hasanudin Univercity Press. Ujungpandang 
Ardiansyah, Asrori. 2015. Pengertian dan Hakikat Disiplin Belajar. (http://aersmile159.wordpress.com/e-learning/pembelajaran/pengertian-danhakikat-disiplin-belajar/), di akses 23 Maret 2020 jam 22.00 WIB

Arrahmi, Syukron Zahidi. 2013. "Pengaruh Kedisiplinan Dan Kemandirian Siswa Terhadap Hasil Belajar IImu Pengetahuan Sosial Kelas V SDN Se-Kecamatan Kebumen" Sripsi-S1. Surakarta : Universitas Sebelas Maret Surakarta Azwar, Saifuddin. 2010. Metode Penelitian. Yogyakarta: Pustaka Pelajar Cangara, Hafied. 2000. Pengantar IImu Komunikasi. PT. Raja Grafindo Persada. Jakarta

Hadi, Sutrisno. 2007. Metodologi Research. Yogyakarta: Andi Yogyakarta Imron, Ali. 2004. Manajemen Siswa Berbasis Sekolah. Jakarta: Bumi Aksara. Nawawi, Hadari. 1990. Administrasi Pendidikan. Jakarta : Gunung Agung Purwanto, Ngalim. 1996. Psikologi Pendidikan. Bandung: PT. Remaja Rosdakarya Rukin. 2013. Disiplin dalam Belajar. (http://selidik86.blogspot.com/2013/03/disiplindalam-belajar.html). Diakses 17 Maret 2020 Jam 19.20 WIB

Slameto. 1991. Belajar dan Faktor-Faktor yang Mempengaruhinya. Jakarta: Bina Aksara

Sudjana, Nana. 2005. Dasar-Dasar Proses Belajar Mengajar. Bandung: Rosdakarya Walgito, Bimo. 1997. Pengantar Psikologi Umum. Yogyakarta: Andi Offset Wijaya, Cece. 1994. Faktor-Faktor Belajar Mengajar. Jakarta: Rajawali Pers. 